Електронне наукове фахове видання з економічних наук "Modern Economics", №21 (2020), 13-18 https://modecon.mnau.edu.ua | ISSN 2521-6392

JEL Classification: M41, Q5, R11

DOI: https://doi.org/10.31521/modecon.V21(2020)-02

Anggeraini Ela, Postgraduate Student, Faculty of Economy, Sriwijaya University, Palembang, Indonesia

ORCID ID: 0000-0001-9397-0169

e-mail: elaanggeraini@gmail.com Indonesia

Wahyudi Tertiarto, Doctor (Economics), Lecturer at Faculty of Economy, Sriwijaya University, Palembang,

ORCID ID: 0000-0003-4056-5105

e-mail: tertiarto_wahyudi@unsri.ac.id

Yusnaini, Doctor (Economics), Lecturer at Faculty of Economy, Sriwijaya University, Palembang, Indonesia

ORCID ID: 0000-0003-4153-9582

e-mail: yusnaini_msi@yahoo.com

\title{
Factors Affecting Environmental Disclosure In Textile And Garment Companies
}

Abstract. Environmental problems are now important concerns for the investors and government. In the case of textile and garment companies, many have not fully paid attention to the surrounding environment. This research was conducted to analyze the effect of media coverage and the board of commissioners on environmental disclosure in 14 textile and garment companies listed on the Indonesia Stock Exchange (IDX) in 2015-2018. The study acquired data through library study methods and documentation. The data were analyzed using panel data regression, and the documentation was examined by the eviews program. The results of the study were expected to be a reference material for further research that related to environmental disclosure.

Purpose. The purpose of the article is to analyze the influence of media and the board of commissioners' coverage on environmental disclosure in textile and garment companies listed on the Indonesia Stock Exchange (BEI) in 2015-2018.

Result. The results of the study stated that (1) the media coverage influenced the environmental disclosure, (2) the size of the board of commissioners provided an influence on the environmental disclosure, (3) the educational background of the board of commissioners influenced the environmental disclosure and (4) the proportion of independent commissioners gave no effect on the environmental disclosure.

Conclusion. The results of this study indicate that the average value of environmental disclosure of textile and garment companies in Indonesia is still very low (19\%). Companies must disclose environmental disclosure information to minimize information asymmetry in the annual report. Furthermore, an improvement in media coverage and both the size and the educational background of the board of commissioners will increase the environmental disclosure. On the other hand, no significant influence occurs from the proportion of board commissioners to the growth of environmental disclosure.

Keywords: environmental disclosure; media coverage; commissioner board size; the proportion of independent commissioner board and the educational background of the commissioner board.

\section{Удк 332.1}

Анггераіні Ела, аспірант, факультет економіки, Університет Шривіджая, Палембанг, Індонезія

Вах'юді Тертіарто, доктор економічних наук, викладач факультету економіки, Університет Шривіджая, Палембанг, Індонезія

Юснаіні, доктор економічних наук, викладач факультету економіки, Університет Шривіджая, Палембанг, Індонезія

\section{Фактори впливу на розкриття інформації про навколишнє середовище в текстильних та швейних компаніях}

Анотація. Екологічні проблеми на сьогодні є важливими для інвесторів та уряду. Більшість текстильних та швейних компаній недостатньо звертають увагу на навколишнє середовище. Це дослідження було проведено з метою аналізу впливу висвітлення в ЗМІ та ради комітетів на розкриття інформації про навколишнє середовище у 14 текстильних та швейних компаніях, що котирувалися на Індонезійській фондовій біржі (IDX) у 2015-2018 роках. Дані для дослідження були отримані завдяки бібліотечним методам та документації та проаналізовано за допомогою регресії даних панелі задач, а документацію вивчено за допомогою Eviews program. Очікувалось, що результати дослідження стануть довідковим матеріалом для подальших досліджень, пов'язаних із розкриттям інформації про навколишнє середовище.

Метою статті є аналіз впливу засобів масової інформації та висвітлення ради комітетів на розкриття інформації про навколишнє середовище в текстильних та швейних компаніях, що котирувалися на Індонезійській фондовій біржі у 2015-2018 роках.

Стаття надійшла до редакції: 05.05.2020

Received: 05 May 2020 
Результати дослідження свідчать, що: висвітлення засобів масової інформації вплинуло на розкриття інформації про навколишнє середовище; розмір ради комітетів мав вплив на розкриття інформації про навколишнє середовище; освіта уповноважених ради комітетів вплинула на розкриття інформації про навколишнє середовище та частка незалежних уповноважених не вплинула на розкриття зазначеної інформації.

Результати досліжження дають змогу зробити висновок, що середня цінність розкриття інформації про навколишнє середовище текстильними та швейними компаніями в Індонезії все ще є дуже низькою (19 відсотків). Компанії повинні розкривати відповідну інформацію про навколишнє середовище, щоб мінімізувати несиметричність інформації у річному звіті. Крім того, поліпшення рівня висвітлення у ЗМI, а також чисельності та рівня освіти ради уповноважених комітетів підвищить повноту розкриття інформації про навколишнє середовище. 3 іншого боку, відсутній суттєвий вплив частки незалежних уповноважених правління на зростання рівня повноти розкриття такої інформації.

Ключові слова: розкриття інформації про навколишнє середовище; висвітлення в засобах масової інформації; розмір ради комітетів; частка незалежних уповноважених та рівень освіти комісії.

Formulation of the problem. Current environmental problems became a very important concern for investors and the government because of the lack of attention and concern of the company towards external economic interests and the interests of the wider community [1]. Based on the cases that occur now, showed that textile and garment companies in Indonesia required supervision and monitor from both stakeholders and shareholders. Regulations governing and providing guidance on social and environmental matters such as ISO 14001 and GRI international standards issued by CSR international were effective from July 1, 2018 [2]. Companies generally convey their concern and responsibility for the environment through environmental disclosure. Environmental disclosure was the disclosure of information about the company's responsibility to the environment stated in financial reports [3].

Based on the Government Regulation No. 40 Year 2007, environmental issues are now a very serious concern of consumers, investors, and governments. One of the environmental problems in Indonesia occurs in the textile and garment industry which becomes an important spotlight on environmental pollution nowadays. Based on a survey conducted by the Wahana Lingkungan Hidup Indonesia [4], the highest environmental case is incurred by the industrial sector as the result of a lack of disclosure of sustainable reports as a form of corporate social responsibility. Following are the average environmental disclosure data for textile and garment companies:

Table 1 The Environmental Disclosure Average

\begin{tabular}{|c|c|}
\hline Year & The Environmental Disclosure Average \\
\hline 2015 & $17 \%$ \\
\hline 2016 & $18 \%$ \\
\hline 2017 & $20 \%$ \\
\hline 2018 & $21 \%$ \\
\hline
\end{tabular}

Source: Author's calculations

Based on the data presented, it appears that environmental disclosure is still very low. This happens because some textile and garment companies still do not realize that environmental disclosure is very important to obtain maximum results. Thus, the company is required to report on social and environmental responsibility as a form of corporate responsibility to the community and the environment.

Industry practices care and are environmentally friendly based on how much industry practices can disclose information and how the board of commissioners oversees environmental disclosure. Disclosure of environmental information provides several benefits to various parties, including the attractiveness of shareholders and stakeholders [5]. However, the lack of public access to data and information on natural resources still becomes a problem. Consequently, limited community participation in the environment and a decline in investment over the years occurred.

The writers conducted the study to determine the relationship between media coverage and the board of commissioners on environmental disclosure in textile and garment companies listed on the Indonesia Stock Exchange in the 2015-2018 period. This study consisted of independent variables from media coverage and the board of commissioners projected in the form of media, the board size, the proportion of the board of commissioners, and the educational background of the board of commissioners. The dependent variable in this study was environmental disclosure. Environmental disclosure was measured by content analysis, which was a combination of narrative, value, and visual images in an analysis of the measurement of environmental disclosure.

Analysis of recent research and publication. The theory of externality is the behavior of one party to another party as the result of a company's indifference to the external economic interests or the interests of the wider community. There are two types of externality: positive externality and negative externality. Positive externality happens when an activity produces benefits to other parties, while negative externality is an activity that creates costs that should be borne by the community [1].

The result of research conducted by Effendi et al. [6] indicated that the size of the board of commissioners, the 
proportion of independent board of commissioners, and the educational background of the board of commissioners did not give significant effects on environmental disclosure because the board of commissioners had no interest in disclosure. Therefore, none of them paid attention to environmental management. Anggrarini [7] stated that the size of the board of commissioners and company size did not have significant effects on environmental disclosure. The board of commissioners focused more on the financial aspects than on the environmental ones. In addition, the size of the company was not considered an obligation for a company.

Solikhah and Winarsih [8] stated that the media coverage, gender diversity, and institutional ownership gave no influence on environmental disclosure because media coverage still possessed limitations on media measurement. Also, gender diversity rejected the hypothesis because the environmental disclosure would still be oversight whether female members existed or not in the company's board of commissioners. Furthermore, institutional ownership rejected the hypothesis too because high and low institutional ownership did not affect the improvement of environmental disclosure quality. Akrout and Othman [9] explained that the majority of companies in their study provided a separate section for environmental issues in their annual reports. Besides, the multivariate analysis showed that there was a negative relationship between the proportions of the board of commissioners on environmental disclosure. However, the presence of government ownership might improve the practice of reporting on the company's environment.

Fashikhah at el. [10] described in their study that 1) managerial ownership negatively influenced environmental disclosure in Indonesia, but it did in Malaysia, 2) there was a positive impact on the size of the board of commissioners on environmental disclosure in Indonesia, but there was a different case in Malaysia, 3) the size of the company did not influence environmental disclosure in Indonesia, but it did in Malaysia, 4) liquidity provided a negative effect on environmental disclosure in Indonesia, but it gave a positive influence in Malaysia, and
5) there was a difference in the level of environmental disclosure in Indonesia and Malaysia.

Finally, Rabbi [11] explained that the level of awareness among Jordanian companies increased during 2014-2017. However, the level of environmental disclosure was still relatively low compared to developed countries. There was a positive relationship between the size of the board of commissioners, the board of managerial ownership and the size of the company on the level of environmental disclosure.

Formulation of research goals. The researchers conducted this study to analyze the influence of media and the board of commissioners' coverage on environmental disclosure in textile and garment companies listed on the Indonesia Stock Exchange (BEI) in 2015-2018.

Description of the main research material. This study consisted of two variables: independent and dependent variables. The media coverage, the proportion of independent commissioners, and the educational background of the board of commissioners were the independent variables. On the other hand, the environment disclosure variable was the dependent one. The writer conducted a partial experimental study. Before conducting the test, the writer would measure the independent and dependent variables with the specified proxy. The secondary data in this study were annual financial reports of textile and garment companies listed on the Indonesia Stock Exchange (IDX) for the 2015-2018 period.

The data collection method was the documentation review, which included financial statements and other supporting data. The collected data was the company's financial reports or annual reports published at www.idx.co.id. The population in this study were 19 textile and garment companies listed on the Indonesia Stock Exchange (IDX) for the 2015-2018 period. The writers took the sample using a purposive sampling technique. In addition, they used the panel regression model to discover the significance of the influence of independent variables on the dependent variable.

The following table shows the sample selection process:

Table 2 Sample Selection Process

\begin{tabular}{|l|c|}
\hline \multicolumn{1}{|c|}{ Criteria } & Total \\
\hline Textile and Garment companies listed on Indonesian Stock Exchange for the periode of 2015-2018; & 19 \\
\hline $\begin{array}{l}\text { Textile and Garment companies that did not have complete data related to the research variables used } \\
\text { for the periode of 2015-2018; }\end{array}$ & 5 \\
\hline Total of Unit Sample & 14 Companies \\
\hline $\begin{array}{l}\text { Research period is 4 years, then the total of unit sample } \\
\text { (14 Companies } \times 4 \text { years) }\end{array}$ & 56 Observation \\
\hline
\end{tabular}

Source: author's calculations

The model equation is written as follows:

$E D_{i t}=\alpha+\beta_{1} L_{i t}+\beta_{2} U K_{i t}+\beta_{3} P D K_{i t}+\beta_{3} P D K_{i t}+\beta_{4} L_{B P D K}+e_{i t}$ Information:
EDit: Environmental disclosure;

$\alpha$ : Constants

$\beta$ : Regression Coeficient for each variable $\mathrm{LM}_{1}$ : Media Coverage 
Електронне наукове фахове видання з економічних наук "Modern Economics", №21 (2020), 13-18 https://modecon.mnau.edu.ua | ISSN 2521-6392

$\mathrm{UDK}_{2}$ : Board of Commissioners Size

$\mathrm{PDK}_{3}$ : Board of Commissioners Propotion

LBPDK 4 : Educational background of Board Commissioners

Economics $=1$, non-economics $=0$

e: Error term $\mathrm{i}=1, \ldots, \mathrm{n}$ : Total number of cross section

$\mathrm{t}=1, \ldots, \mathrm{t}$ : Total number of time series

Based on the literature review, the framework of this study was shown in the following figure:

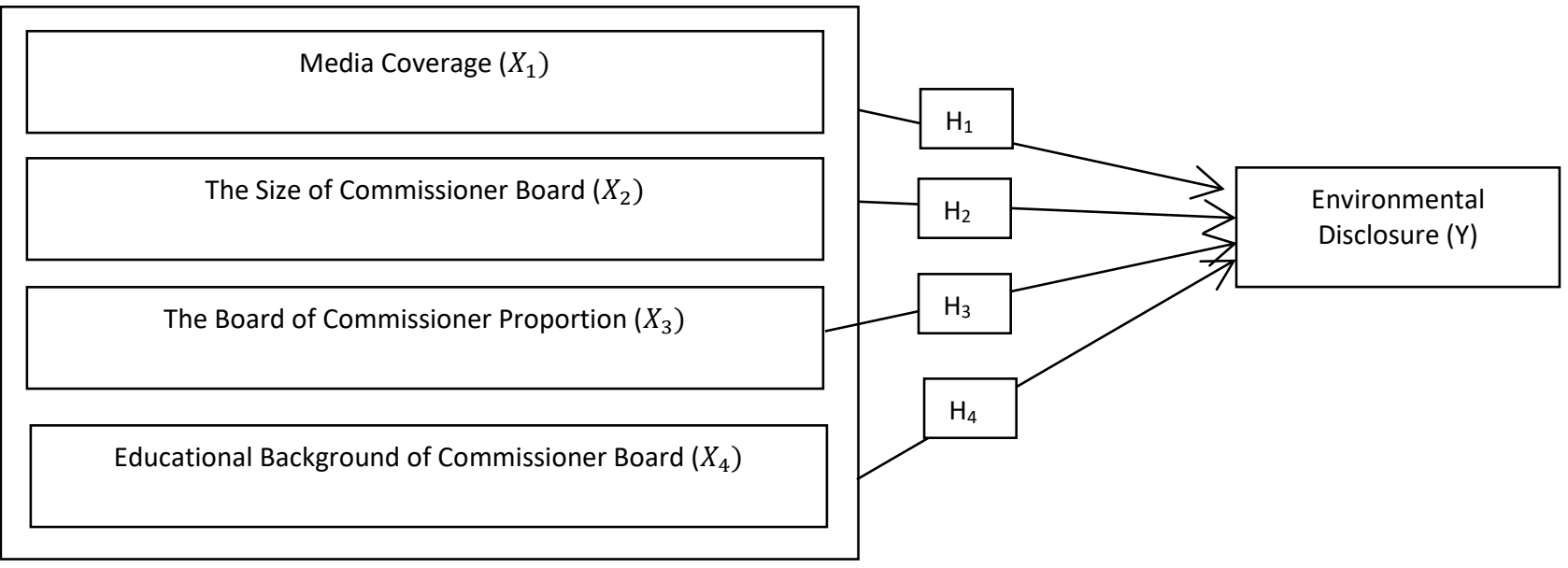

Figure 1 - Conceptual Framework

Source: author's calculations

Figure 1 was the theoretical framework analyzed to see the effects of media and board of commissioners on the environmental disclosure in the textile and garment companies listed on the Indonesia Stock Exchange in the 2015-2018 period. Based on the literature review, the hypotheses constructed from this research were:

1. Hypothesis 1: media coverage has a positive influence on environmental disclosure

2. Hypothesis 2: the size of the board of commissioners has a positive influence on environmental disclosure
3. Hypothesis 3: The proportion of independent commissioners has a positive influence on environmental disclosure

4. Hypothesis 4: Board of Commissioners' educational background has a positive influence on environmental disclosure.

Based on the results of the Hausman test conducted, the most appropriate model for panel data regression in this study is the random effect model.

Table 3 Model Summary Panel Data Regression Output Result

\begin{tabular}{|c|c|c|c|c|}
\hline Variable & Coefficient & Std. Error & t-Statistic & Prob. \\
\hline C & 0.138492 & 0.021719 & 6.376658 & 0.0000 \\
\hline LM & 0.007997 & 0.002464 & 3.245805 & 0.0021 \\
\hline UDK & 0.008161 & 0.003778 & 2.160410 & 0.0355 \\
\hline PDK & -0.023152 & 0.033188 & -0.697606 & 0.4886 \\
\hline LBPDK & 0.018166 & 0.007434 & 2.443826 & 0.0180 \\
\hline R-squared & 0.256872 & \multicolumn{2}{|c|}{ Mean dependent var } & 0.064516 \\
\hline Adjusted R-squared & 0.198587 & \multicolumn{2}{|c|}{ Sum squared resid } & 0.023721 \\
\hline S.E. of regression & 0.021235 & \multicolumn{2}{|}{ Durbin-Watson stat } & 1.022998 \\
\hline F-statistic & 4.407200 & \multicolumn{2}{|l}{} \\
\hline Prob(F-statistic) & 0.003891 & \multicolumn{2}{|l}{} \\
\hline
\end{tabular}

Source: author's computation

Based on table 3, the panel data regression model equation is obtained as follows:

$$
\begin{aligned}
& Y_{i t}=0.138492+0.007997 \mathrm{LM}_{i t}+0.008161 U D K_{i t}{ }^{-} \\
& \quad 0.023152 P D K_{i t}+0.018166 L_{B P D K_{i t}}+\varepsilon
\end{aligned}
$$

Based on the calculation, the R2 is 0.26 . It indicates that the influence of the media coverage, the board of commissioner's size, proportion, and educational background on the environmental disclosure was $26 \%$, while the other factors caused the remaining $74 \%$.

The Relationship between Media Coverage on Environmental Disclosure. The t value was 3.245805 with a probability level of $0.0021(p<0.05)$ and a coefficient value of 0.007997 . It showed that media coverage (LM) gives a significant positive effect on environmental disclosure. Thus, the first hypothesis $(\mathrm{H} 1)$ is accepted. The 
positive coefficient value indicates that if the variable media coverage increases, the level of environmental disclosure will improve. On the other hand, environmental disclosure will decline when the media coverage variable decreases.

The results of this study are in line with Brosius \& Kepplinger [12] and Ayuso \& Larrinaga [13], which stated that media coverage influences environmental disclosure. Therefore, the results of hypothesis testing are relevant to the theory of externalities as the environmental disclosure through the media provides positive externalities for other parties such as the public or investors. As the resource for a company to make environmental disclosure, media coverage aims at providing maximum information and benefits to them.

The Relationship of the Board of Commisioner's Size on Environmental Disclosure. The t value was 2.160410 with a probability level of $0.00355(p<0.05)$ and a coefficient value of 0.0088161 , which reveals that the board size has a positive and significant impact on environmental disclosure. Thus, the second hypothesis (H2) is accepted. The positive coefficient value indicates that if the variable size of the board of commissioners rises, the level of environmental disclosure will develop. On the other hand, then environmental disclosure will reduce if the board size variable declines.

The results of this study are in line with Solikhah and Winarsih [8], Fashikhah et al. [10], Amelia and Cahyati [14], Rabbi [11], and Sun et al. [15] who found that the size of the board of commissioners has a positive and significant effect on environmental disclosure. Hence, this research is in line with the theory of externalities. The rationale for this theory explains that every company should be aware that the effect of consumption or production actions must meet the value society has and provide positive externalities to society by having a sense of concern for the environment.

The Relationship of the Board of Commissioner Proportion on Environmental Disclosure. The $t$ value was -0.697606 with a probability level of $0.4886(p>0.05)$ and a coefficient value of -0.023152 . It shows that the proportion of the board of commissioners has a negative and significant influence on environmental disclosure. Thus, the result rejected the third hypothesis $(\mathrm{H} 3)$. The negative coefficient value indicates that the level of environmental disclosure will grow if the variable proportion of the board of commissioners declines. In contrast, when the variable proportion of the board of commissioners progresses, the environmental disclosure will reduce.

The results of this study are in line with Solikhah and Winarsih [8], Effendi et al. [6], Suhardjanto and Permatasari [16], and Suhardjanto and Afni [17] who stated that the proportion of the board of commissioners has no positive and significant effect on environmental disclosure. It indicates that this research does not support the theory of externalities. Based on the results of this study, the proportion of the board of commissioners who are in textile and garment companies cannot fully carry out their duties independently.

The Relationship of the Board of Commissioners' Educational Background on Environmental Disclosure. The $t$ value was 2.443826 with a probability level of 0.0180 $(p<0.05)$ and a coefficient value of 0.018166 . Hence, the educational background of the commissioners has a positive and significant impact on environmental disclosure. Thus, the fourth hypothesis (H4) is accepted. The positive coefficient value indicates that if the education background variable of the board of commissioner increase, the level of environmental disclosure will grow. But, if the educational background variable of the board of commissioners decreases, the environmental disclosure will reduce.

The results of this study are in line with Effendi et al. [6] and Rahmawati et al. [18]. The educational background of the board of commissioners has a positive and significant effect on environmental disclosure. It indicates that hypothesis testing is relevant to the theory of externalities as the economic educational background indicators can improve management and decision making. Thus, environmental externalities do not occur.

Conclusions. Based on the results of analysis and testing, the researchers conclude that media coverage, the board of commissioners size, and educational background have positive and significant effects in increasing the environmental disclosure of textile and garment companies in Indonesia. Therefore, every development in media coverage, the size of the board of commissioners, and their educational background will increase environmental disclosure. However, the proportion of the board of commissioners is proven to have no significant influence on the increase of environmental disclosure. The results of the study were expected to be a reference material for further research that related to environmental disclosure.

\section{References:}

1. Murni, A. (2016). Ekonomi Makro Edisi Revisi. Bandung: PT Refika Aditama.

2. GRI-G4. (2015). Sustainability Reporting Guidelines, Reporting Principles and Standard Disclosure. Retrieved from www.globalreportinginitiative.org

3. Paramitha \& Rohman, A. (2014). Pengaruh karakteristik perusahaan terhadap environmental disclosure. Diponegoro Journal of Accounting, 3(3), 1-11.

4. Walhi, (2018). Kondisi Indonesia Masih Darurat Ekologis. Retrieved from http://www.walhi.or.id

5. Flieger, J., Fischer, M., Kupfer, T., \& Eyerer, P. (2015). The contribution of life cycle assessment to global sustainability reporting of organizations. Management of Environmental Quality: An International Journal Article information, 16(2), 167-179. 
Електронне наукове фахове видання з економічних наук “Modern Economics», №2 1 (2020), 13-18 https://modecon.mnau.edu.ua | ISSN 2521-6392

https://doi.org/10.1108/14777830510583182.

6. Effendi et al. (2012). Faktor - Faktor yang Mempengaruhi Tingkat Pengungkapan Tanggung jawab Lingkungan dalam Laporan Tahunan. JEAM, 11(2), 19-32.

7. Anggrarini, D., \& Taufiq, E. (2016). The Affect of The Size of Commissioners Board and The Size of the Company Regarding to The Enviromental Disclosure. The Accounting Journal of Binaniaga, 01(02), 35-42.

8. Solikhah, B., \& Winarsih, A. M. (2016). The Effect of Media Coveage, Industry Sensitivity and Corporate Governance Structure to Environmental Disclosure Quality. Jurnal Akuntansi Dan Keuangan Indonesia, 13(1), 1-22.

9. Akrout, M. M., \& Othman, H. Ben. (2016). Oenwrship structure on environmental disclosure in Mena Emerging countries. Corporate Ownership \& Control, 13(4), 381-388.

10. Fashikhah, I., Rahmawati, E., \& Sofyani, H. (2018). Determinan Environmental Disclosure Perusahaan Manufaktur di Indonesia dan Malaysia. Jurnal Akuntansi Indonesia, 7(1), pp. 31-55.

11. Rabi, A. M. (2019). Board Characteristics on Environmental Disclosure: Evidence from Jordan. International Journal of Business and Management, 14(2), 57-65. https://doi.org/10.5539/ijbm.v14n2p57.

12. Brosius, H.-B. \& Kepplinger, H. M. (1990). The Agenda-Setting Function of Television News Static and Dynamic Views. Communication Research, 17(2), 183-211.

13. Ayuso, M. G. \& Larrinaga, C. (2014). Environmental Disclosure in Spain: Corporate Characteristics and Media Exposure. Spanish Journal of Finance and Accounting (October), 184-214. https://doi.org/10.1080/02102412.2003.10779479.

14. Amelia, \& Cahyati, A. D. (2015). Pengaruh Kinerja Keuangan, Kinerja Lingkungan, Size, dan Ukuran Dewan Komisaris terhadap Environmental Disclosure. JRAK, 6(2), 64-79.

15. Sun, N., Salama, A., Hussainey, K., \& Habbash, M. (2010). Corporate environmental disclosure, corporate governance and earnings management. Managerial Auditing Journal, 25(7), 679-700.

16. Suhardjanto, D., \& Permatasari, N. D. (2010). Pengaruh Corporate Governance terhadap Environmental Disclosure dengan Environmental Performance sebagai Variabel Moderating. Jurnal Kinerja, 14(2), 151-164.

17. Suhardjanto, D. \& Afni, A. N. (2009). Praktik Corporate Disclosure di Indonesia. Studi Empiris di Bursa Efek Indonesia. Jurnal Akuntansi, 14(2), 125-139.

18. Rahmawati, M. I. \& Subardjo, A. (2017). Pengaruh Pengungkapan Lingkungan dan Kinerja Lingkungan Terhadap Kinerja Ekonomi yang di Moderasi Good Corporate Governance. Jurnal Buletin Studi Ekonomi, 22(2), 200-226. 